\title{
Editorial: Research on Applied Ethics involving emerging ICT technologies
}

Matthew Warren

Deakin University

\section{Oliver Burmeister}

Charles Sturt University

oburmeister@csu.edu.au

This is the inaugural special section on applied ethics for AJIS. There is a link between Information system and ethics. This link can be traced back to the early days of computers and the ethical issues regarding the manner in which information could be used or misused, this relationship is often described as "Information Ethics" (Floridi, 2006). The concept of Information Ethics has never been more relevant than today, the way that organisations and governments can use and manipulate people's information to change their purchasing habits or even their voting habits.

Two guest editors were appointed, Professor Matthew Warren (Deakin University) and Associate Professor Oliver Burmeister (Charles Sturt University). Nine submissions were received, of which three were accepted for this special section. An overview of those three follows, after which the guest editor backgrounds are described.

The three accepted articles cover a broad spectrum of applied ethics to do with emerging technologies, from mobile health (mHealth), to considerations of autonomy and to professional ethics.

The paper by O'Connor et al., focuses on applied ethics as it conducts a philosophical examination from a moral standpoint of a public health issue that necessitates moral judgment of caregivers of children. Some mHealth technologies, such as smart phone technologies, have been around for a long time, yet new ones keep emerging, including new applications for old technologies, again including smart phones. The paper on autonomy considerations and emerging ICTs is a different sort of exploration of applied ethics. For example, it raises an old issue in the philosophy of technology, in a new context, by relating the role of autonomy in technology design. The paper on professional ethics brings a different perspective again. It examined the common challenges and strategies for solving them, related to all technology development and management, rather than any specific technology. It addresses how professionals can better consider ethical implications of any technology. In relation to the acceptance of this paper on professional ethics, which was co-authored by one of the guest editors, it should be noted that he was not involved in any of the reviewing and editorial decision making for that paper. Instead those tasks were carried out by the Editor-in-Chief of AJIS. The AJIS editorial system was set-up such that Dr Burmeister could not see that submission, nor any processing of it.

About the guest editors. This editorial marks the first joint publication between these two. However, for the past two decades they have frequently served together on committee work. That has been particularly evident on two fronts. Firstly, they were both executive members of the Australasian Institute on Computer Ethics (AiCE), which in the early 2000 s had over 30 institutional members, and represented not only ICT professionals, but also those in the ICT industry whose primary work was other than ICT (such as engineering), and who therefore did not qualify for membership of the ICT professional body, the Australian Computer Society (ACS). Both, at different times, served as AiCE Director. Both served on numerous organising committees of the bi-annual AiCE conferences. Secondly, both have been and continue to be members of the ACS Ethics Committee. Professor Matthew Warren has published eight times in AJIS over the past 16 years (Senarathna, et al, 2016, Pye and Warren 2006, Pierce, et al 2006, Leitch and Warren 2003, Warren and Hutchinson 2003, Hutchinson and Warren 2002a, Hutchinson and Warren 2002b, Hutchinson and Warren 2001). Professor Warren has 
recently changed his academic role at Deakin University from being a Chair of Information Systems to a Professor of Cyber Security, much of his current research is focused on ethical issues in relation to cyber security. Associate Professor Burmeister has published five times in AJIS over the past 22 years (Bowern, Burmeister, Gotterbarn, \& Weckert, 2006; Burmeister, 1995, 2015; Burmeister, Islam, Dayhew, \& Crichton, 2015; Simpson, Nevile, \& Burmeister, 2003). Most of his ICT ethics work been in the areas of value sensitive design (Burmeister, 2010, 2012, 2016; Burmeister, Weckert, \& Williamson, 2011; Pakrasi, Burmeister, McCallum, Coppola, \& Loeb, 2015; Teipel et al., 2016) and professional ethics (Berleur et al., 2008; Burmeister, 2000, 2013, 2017; Burmeister \& Sharma, 2005; Burmeister \& Weckert, 2003).

\section{References}

Berleur, J., Burmeister, O., Duquenoy, P., Gotterbarn, D., Goujon, P., Kaipainen, K., Whitehouse, D. (Eds.). (2008). Ethics of Computing Committees: Suggestions for Functions, Form, and Structure. Laxenburg, Austria: IFIP Press.

Bowern, M., Burmeister, O. K., Gotterbarn, D., \& Weckert, J. (2006). ICT Integrity: Bringing the ACS Code of Ethics up to date. Australasian Journal of Information Systems, 13(2), 168-181. doi:http://dx.doi.org/10.3127/ajis.v13i2.50

Burmeister, O. K. (1995). Evaluating the factors that facilitate a deep understanding of data analysis. Australasian Journal of Information Systems, 3(1). doi:http://dx.doi.org/10.3127/ajis.v3i1.390

Burmeister, O. K. (2000). Applying the ACS code of ethics. Journal of Research and Practice in Information Technology, 32(2), 107-120.

Burmeister, O. K. (2010). Websites for seniors: Cognitive accessibility. Australian Journal of Emerging Technologies and Society, 8(2), 99-113. Retrieved from https://www.scopus.com/inward/record.uri?eid=2-s2.0-

79251542361\&partnerID=40\&md5=7a8odode2e5e424552b196b2f71fac56

Burmeister, O. K. (2012). What seniors value about online community. Journal of Community Informatics, 8(1). Retrieved from http://cijournal.net/index.php/ciej/article/view/545

Burmeister, O. K. (2013). Achieving the goal of a global computing code of ethics through an international-localisation hybrid. Ethical Space: The International Journal of Communication Ethics, 10(4), 25-32.

Burmeister, O. K. (2015). Improving professional IT doctorate completion rates. Australasian Journal of Information Systems, 19, 55-70. doi:10.3127/ajis.v19io.1073

Burmeister, O. K. (2016). The development of assistive dementia technology that accounts for the values of those affected by its use. Ethics and Information Technology, 18(3), 185198. doi:10.1007/s10676-016-9404-2

Burmeister, O. K. (2017). Professional Ethics in the Information Age. Journal of Information, Communication \& Ethics in Society, 15(2).

Burmeister, O. K., Islam, M. Z., Dayhew, M., \& Crichton, M. (2015). Enhancing client welfare through better communication of private mental health data between rural service providers. Australasian Journal of Information Systems, 19, 1-14. doi:http://dx.doi.org/10.3127/ajis.v19io.1206

Burmeister, O. K., \& Sharma, A. (2005). Professionalism in ICT: meeting the challenge of ethical dilemmas in the workplace. Paper presented at the Fourth Australian Institute of Computer Ethics Conference, Deakin University, Geelong.

Burmeister, O. K., \& Weckert, J. (2003). Applying the new software engineering code of ethics to usability engineering: A study of 4 cases. Journal of Information, Communication \& Ethics in Society, 3(3), 119-132. 
Burmeister, O. K., Weckert, J., \& Williamson, K. (2011). Seniors extend understanding of what constitutes universal values. Journal of Information, Communication \& Ethics in Society, 9(4), 238-252. doi:10.1108/14779961111191048

Hutchinson W and Warren M (2001) Information warfare and ethics, Vol. 8, pp. 58-62, Australasian Journal of Information Systems, Wollongong, NSW, Australia.

Hutchinson W, and Warren M (2002a) Information warfare: using the viable system model as a framework to attack organisations, Vol. 9, pp. 67-74, Australasian Journal of Information Systems, Wollongong, NSW, Australia.

Hutchinson W and Warren M (2002b) Information warfare: using the viable system model as a framework to attack organisations, Vol. 9, pp. 67-74, Australasian Journal of Information Systems, Wollongong, NSW, Australia.

Floridi, L. (2006) "Information Ethics, its Nature and Scope" SIGCAS Computers and Society (36:3), pp. $21-36$

Leitch S, and Warren M (2003) Designing systems for e-commerce, Vol. 10, pp. 139-143, Australasian Journal of Information Systems, Canberra, ACT, Australia.

Pierce J, Jones A, and Warren M (2006) Penetration testing professional ethics: a conceptual model and taxonomy, Vol. 13, pp. 193-200, Australasian Journal of Information Systems, Canberra, ACT, Australia.

Pakrasi, S., Burmeister, O. K., McCallum, T. J., Coppola, J. F., \& Loeb, G. (2015). Ethical telehealth design for users with dementia. Gerontechnology, 13(4), 383-387. doi:10.4017/gt.2015.13.4.002.00

Pye, G and Warren, M (2006), Striking a balance between ethics and ICT governance, Vol. 13, pp. 201-207, Australasian Journal of Information Systems, Canberra, ACT, Australia.

Senarathna, I, Yeoh G, Warren M, and Salzman , S. (2016) Security and privacy concerns for Australian SMEs cloud adoption: empirical study of metropolitan vs regional SMEs, Vol. 20, pp. 1-20, Australasian Journal of Information Systems, Canberra, ACT, Australia.

Simpson, C., Nevile, L., \& Burmeister, O. K. (2003). Doing Ethics: A Universal Technique in an Accessibility Context. Australasian Journal of Information Systems, 1O(2). doi:http://dx.doi.org/10.3127/ajis.v10i2.159

Teipel, S., Babiloni, C., Hoey, J., Kaye, J., Kirste, T., \& Burmeister, O. K. (2016). Information and communication technology solutions for outdoor navigation in dementia. Alzheimer's \& Dementia: The Journal of the Alzheimer's Association, 12(6), 695-707. doi:10.1016/j.jalz.2015.11.003

Warren M, and Hutchinson, W (2003) Australian hackers and ethics, Vol. 10, pp. 151-156, Australasian Journal of Information Systems, Canberra, ACT, Australia.

Copyright: (C) 2017 Warren \& Burmeister. This is an open-access article distributed under the terms of the Creative Commons Attribution-NonCommercial 3.0 Australia License, which permits non-commercial use, distribution, and reproduction in any medium, provided the original author and AJIS are credited. 


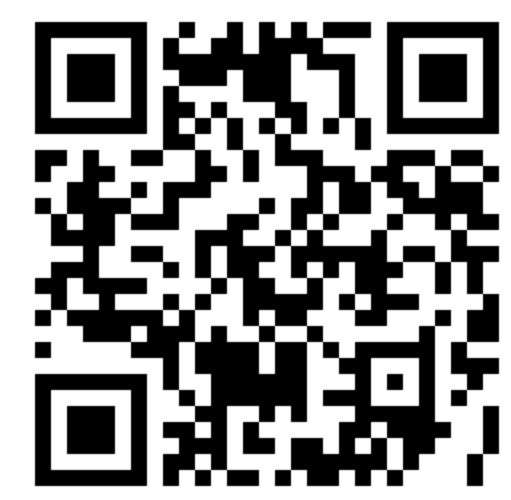

